\title{
EFEK AQUATIC AEROBIC ACTIVITY TERHADAP PERKEMBANGAN KEMAMPUAN BASIC MOTOR CONTROL, GROSS MOTOR DAN OCCUPATIONAL PERFORMANCE SKILLS PADA ANAK CEREBRAL PALSY (CP)
}

\author{
Hendri Kurniawan, Erayanti Saloko \\ Kementerian Kesehatan Politeknik Kesehatan Surakarta Jurusan Okupasi Terapi
}

\begin{abstract}
Aquatic Aerobic Activity, Land Based Activity, Motor Control. Cerebral palsy $(C P)$ is characterized by sensorimotor disorders of motor control control (gross motors and fine motor) as well as posture. Aquatic aerobic activity is designed to give sensorimotor stimulation through a series of activities undertaken in the pool. Indicators of sensorimotor function improvement in $C P$ can be evaluated through changes in the motion control capabilities, basic motor control in the setting of functional posture, and the ability to perform functional activities. The purpose of this study was to examine the effect of aerobic aquatic activity towards the development of motor abilities, basic motor control, and occupational performance skills in children with $C P$. The study design was performed according to quasi experimental design with control group pretest-posttest design. The study population was patients with CP that received rehabilitation treatment in occupational therapy unit YPAC Surakarta. Sampling using quota sampling with a sample size of 30 people. Analysis of data using paired samples t-test, Wilcoxon and Mann-Whitney using SPSS version 16.0. The average value of the change scores Bobath Chart and GMFM post-intervention aquatic aerobic activity amounted to 4.07 and 7.33, while the post-intervention land based activity amounted to 0.80 and 1.53. The test results paired sample t-test for Bobath Chart scores and GMFM scores before and after intervention showed p-value <0.05. The results of the comparative analysis showed a significant difference ( $p$-value <0.05) between the changes Bobath Chart scores and GMFM scores between the intervention group aquatic aerobic activity with land based activity. Performance and satisfaction scores increased by 0.13 and 0.47 (aquatic aerobic activity) and $0.07 \& 0.27$ (land based activity). Aquatic Aerobic Activity results significant effect towards basic motor control, gross motor and occupational performance skills in children with CP.
\end{abstract}

Keywords : Aquatic Aerobic Activity, Land Based Activity, Motor Control

Abstrak : Aquatic Aerobic Activity, Land Based Activity, Motor Control. Cerebral palsy $(\mathrm{CP})$ mengalami gangguan fungsi sensorimotor yang spesifik berupa gangguan kontrol gerak (gross motor maupun fine motor) dan postur secara adekuat. Aquatic aerobic activity didesain untuk memberikan stimulasi sensorimotor melalui serangkaian aktivitas yang dilakukan di kolam renang. Indikator perbaikan fungsi sensorimotor pada anak CP dapat dievaluasi melalui perubahan kemampuan kontrol gerak, basic motor control dalam pengaturan postur tubuh yang fungsional serta kemampuan dalam melakukan aktivitas fungsional. Tujuan penelitian ini adalah untuk mengkaji efek aquatic aerobic activity terhadap perkembangan kemampuan motoris, basic motor 
control, dan occupational performance skills pada anak Cerebral Palsy (CP). Desain penelitian dilakukan menurut rancangan quasi experiment dengan control group pretestpost test design. Populasi penelitian adalah pasien $\mathrm{CP}$ yang memperoleh penanganan rehabilitasi di unit okupasi terapi YPAC Cabang Surakarta. Pengambilan sampel menggunakan teknik quota sampling dengan jumlah sampel sebanyak 30 orang. Analisis data menggunakan uji paired sample t-test, Wilcoxon dan Mann-Whitney dengan memakai program SPSS versi 16.0. Nilai rata-rata perubahan skor Bobath Chart dan GMFM pasca intervensi aquatic aerobic activity sebesar 4,07 dan 7,33, sedangkan pasca intervensi land based activity sebesar 0,80 dan 1,53. Hasil uji paired sample t-test terhadap skor Bobath Chart dan skor GMFM sebelum dan sesudah intervensi menunjukkan nilai p-value $<0,05$. Hasil analisis komparatif menunjukkan adanya perbedaan yang signifikan ( $\mathrm{p}$-value $<0,05$ ) antara perubahan skor Bobath Chart dan skor GMFM antara kelompok yang diintervensi aquatic aerobic activity dengan land based activity. Skor performance dan satisfaction meningkat sebesar 0,13 \& 0,47 (aquatic aerobic activity) dan $0,07 \&$ \& 27 (land based activity). Aquatic aerobic activity memberikan efek yang signifikan terhadap peningkatan kemampuan basic motor control, gross motor, dan occupational performance skills pada anak cerebral palsy.

\section{Kata Kunci : Aquatic Aerobic Activity, Land Based Activity, Motor Control}

\section{PENDAHULUAN}

Cerebral palsy (CP) merupakan penyakit kronik yang mengenai pusat pengendalian gerak dengan manifestasi klinis yang tampak pada beberapa tahun pertama kehidupan, berupa gangguan kemampuan otak untuk mengontrol gerak dan postur secara adekuat (Saharso, 2006). Gangguan kontrol motorik (gerak) pada pasien CP, baik motorik kasar maupun motorik halus, berdampak pada masalah keseimbangan, berjalan dan kesulitan dalam melakukan aktivitas fungsional sehari-hari.

Penanganan rehabilitasi pada pasien $\mathrm{CP}$ bertujuan untuk memperbaiki kecacatan secara sensoris dan motoris, mencegah kontraktur dan meningkatkan kemampuan fungsional pasien melalui latihan . Okupasi terapi merupakan salah satu profesi yang memberikan intervensi terhadap anak berkebutuhan khusus, salah satunya adalah cerebral palsy, dengan tujuan utama mencapai kemandirian fungsional dan memaksimalkan kinerja okupasional. Tujuan intervensi okupasi terapi terhadap anak CP dapat dicapai melalui beberapa metode. Meskipun demikian, secara umum penanganan okupasi terapi pada kondisi CP merupakan land based activity. Land based activity yaitu aktivitas terapetik yang dilakukan di atas matras, tempat tidur atau media terapi tertentu seperti : bola, kursi atau meja yang dimodifikasi.

Oleh karena perkembangan kemampuan fungsional pada anak CP dipengaruhi oleh perkembangan kemampuan kontrol motorik, maka penting untuk mengkaji efek aquatic aerobic activity terhadap perkembangan kemampuan basic motor control, gross motor, dan occupational performance skills.

\section{METODE PENELITIAN}

Penelitian ini dilakukan dengan rancangan quasi experiment dengan 
control group pretest-post test design. Proses penelitian dengan rancangan ini diawali dengan pemilihan atau penentuan sampel baik pada kelompok eksperimen/ perlakuan dan kelompok kontrol. Selanjutnya dilakukan pre test pada kedua kelompok penelitian. Kelompok eksperimen diberikan latihan okupasi

terapi berupa kombinasi aquatic aerobic activity dengan land based activity, sedangkan kelompok kontrol menjalani latihan okupasi terapi berupa land based activity. Latihan diberikan selama lebih kurang 8 minggu dengan frekuensi dan durasi yang telah ditentukan. Post test dilakukan diakhir penelitian pada kedua kelompok penelitian dan selanjutnya dilakukan analisis komparatif.

\section{HASIL PENELITIAN \\ Tabel 1}

Distribusi frekuensi sampel penelitian berdasarkan jenis kelamin

\begin{tabular}{ccc}
\hline \multicolumn{1}{c}{ Jenis Kelamin } & Jumlah & $\%$ \\
\hline Laki-laki & 17 & 56,67 \\
Perempuan & 13 & 43,33 \\
\hline Total & 30 & 100 \\
\hline Proporsi & sampel & penelitian,
\end{tabular}

berdasarkan tabel 1 diketahui didominasi oleh sampel berjenis kelamin laki-laki $(56,67 \%)$.

Tabel 2

Distribusi frekuensi sampel penelitian berdasarkan tipe $\mathbf{C P}$

\begin{tabular}{|c|c|c|}
\hline Tipe CP & Jumlah & $\%$ \\
\hline CP Spastik Diplegia & 15 & 50 \\
\hline CP Spastik Quadriplegia & 10 & 33,33 \\
\hline CP Spastik Hemiplegia & 5 & 16,67 \\
\hline Total & 30 & 100 \\
\hline
\end{tabular}

mengalami CP tipe spastik diplegia, yaitu $50 \%$ (Tabel 2).
Tabel 3

Distribusi frekuensi peningkatan skor Bobath Chart sesudah intervensi

\begin{tabular}{|c|c|c|}
\hline \multirow[t]{2}{*}{ Intervensi } & $\begin{array}{c}\text { Mera } \\
\text { ngkak } \\
/ \\
\text { Berlu } \\
\text { tut } \\
(\%)\end{array}$ & $\begin{array}{l}\text { Berdiri } \\
\text { / Jalan } \\
(\%)\end{array}$ \\
\hline & $\begin{array}{c}23 \\
(79)\end{array}$ & $5(100)$ \\
\hline $\begin{array}{l}\text { Aquatic } \quad \text { Aerobic } \\
\text { Activity }\end{array}$ & $1(100)$ & $0(0)$ \\
\hline Land Based Activity & $\begin{array}{c}29 \\
(100)\end{array}$ & $5(100)$ \\
\hline \multicolumn{3}{|l|}{ Total } \\
\hline \multirow[t]{2}{*}{ Intervensi } & \multicolumn{2}{|c|}{$\begin{array}{c}\text { Skor Komponen Bobath } \\
\text { Chart }\end{array}$} \\
\hline & $\begin{array}{cc}\text { Terle } & \text { Tengku } \\
\text { ntang } & \text { rap } \\
(\%) & (\%)\end{array}$ & $\begin{array}{c}\text { Duduk } \\
(\%)\end{array}$ \\
\hline $\begin{array}{l}\text { Aquatic } \quad \text { Aerobic } \\
\text { Activity }\end{array}$ & $17(85)$ & $12(80)$ \\
\hline Land Based Activity & $3(15)$ & $3(20)$ \\
\hline Total & $\begin{array}{c}20 \\
(100) \\
\end{array}$ & $\begin{array}{c}15 \\
(100) \\
\end{array}$ \\
\hline $\begin{array}{l}\text { Pasca in } \\
\text { basic motor con } \\
\text { memperoleh inte } \\
\text { activity menunjuk } \\
\text { lebih besar (790 } \\
\text { pasien CP yang d } \\
\text { based activity } \\
\text { kemampuan basi } \\
\text { pasien CP yang } \\
\text { aerobic activity } \\
\text { seluruh kompone } \\
\text { jongkok. }\end{array}$ & $\begin{array}{l}\text { ervensi, ken } \\
\text { trol pasien } \\
\text { vensi aquatic } \\
\text { kan peningkat } \\
\text {-100\%) dibar } \\
\text { intervensi den } \\
\text { able 3). Pen } \\
\text { motor contr } \\
\text { diintervensi } \\
\text { terjadi pada } \\
\text { n, kecuali kc }\end{array}$ & $\begin{array}{l}\text { yanguan } \\
\text { aerobic } \\
\text { yang } \\
\text { lingkan } \\
\text { an land } \\
\text { gkatan } \\
1 \text { pada } \\
\text { aquatic } \\
\text { hampir } \\
\text { nponen }\end{array}$ \\
\hline
\end{tabular}


Tabel 4

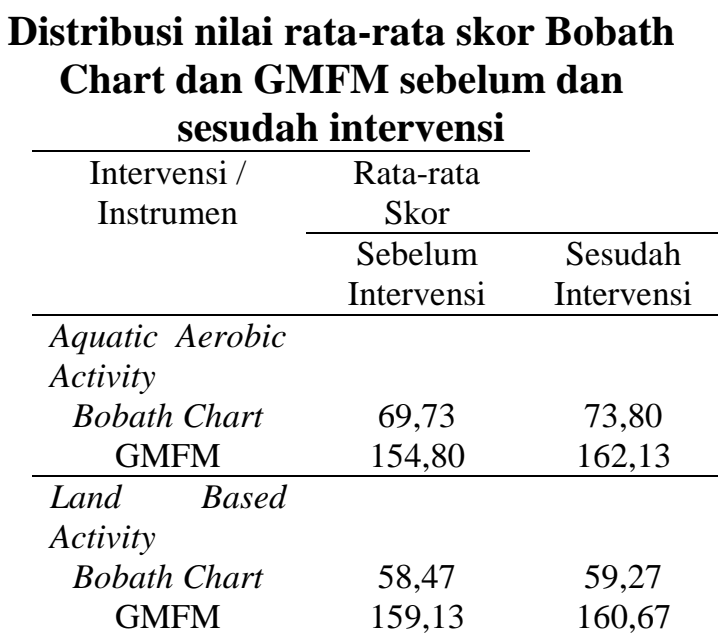

Tabel 5

Distribusi nilai rata-rata perubahan (selisih) skor Bobath Chart dan GMFM sebelum dan sesudah intervensi

\begin{tabular}{cc}
\hline Intervensi / Instrumen & $\begin{array}{c}\text { Rata-rata } \\
\text { Selisih Skor }\end{array}$ \\
\hline Aquatic Aerobic Activity & \\
Bobath Chart & 4,07 \\
GMFM & 7,33 \\
\hline Land Based Activity & \\
Bobath Chart & 0,80 \\
GMFM & 1,53 \\
\hline
\end{tabular}

Dapat diketahui bahwa rata-rata skor Bobath Chart (kemampuan motor control) dan rata-rata skor GMFM (perkembangan gross motor) pasca intervensi terjadi perubahan positif yang mengindikasikan adanya peningkatan kemampuan. Namun rata-rata perubahan yang paling besar terjadi pada kelompok sampel yang memperoleh intervensi aquatic aerobic activity (tabel 5).

\section{PEMBAHASAN}

Cerebral palsy (CP) merupakan suatu penyakit dengan gangguan perkembangan atau kerusakan pada area motorik otak yang berdampak pada kemampuan otak untuk mengontrol pergerakan dan postur secara adekuat (Saharso, 2006). Kondisi ini menyebabkan pasien $\mathrm{CP}$ tidak dapat bermain secara aktif, kurang dapat berpartisipasi dalam permainan di luar ruangan (playground activities), lebih banyak duduk, dan jika mampu berjalan hanya mampu berjalan dengan jarak yang pendek karena mudah lelah. Penurunan aktivitas secara fisik pada pasien $\mathrm{CP}$ menyebabkan keterbatasan pada sistem respirasi, kardiovaskular maupun sistem muskuloskeletal, sehingga memicu terjadinya penurunan daya tahan (endurance) dan penurunan kemampuan fisik (dekondisi) (Fowler et al., 2007). Guna menyikapi keadaan tersebut, maka diperlukan upaya rehabilitasi yang tidak hanya mampu menstimulasi perbaikan kontrol gerak, tetapi juga mampu meningkatkan kemampuan fisik atau ketahanan kardiorespirasi (cardiorespiratory endurance).

Hasil beberapa studi menunjukkan bahwa terapi akuatik dapat meningkatkan kapasitas kardiovaskular (aerobic capacity) dan meningkatkan kekuatan otot (Retarekar et al., 2009) serta meningkatkan kemampuan gross motor (Thorpe et al., 2005). Buoyancy, tahanan (drag force) dan tekanan hidrostatik pada air dapat menjadi media terapi yang mampu memberikan efek terapetik pada saat latihan atau terapi di air. Efek terapetik tersebut diantaranya : peningkatan kekuatan otot, keseimbangan dan peningkatan kapasitas kardiovaskular serta respirasi (Kelly \& Darrah, 2005). Peningkatan kapasitas kardiovaskular dan respirasi akan mempengaruhi kecukupan oksigen ke seluruh jaringan pada tubuh sehingga dapat memicu peningkatan metabolisme di tingkat sel, tidak terkecuali di sel saraf.

Peningkatan metabolisme di sel saraf dapat mempengaruhi peningkatan 
produksi (sekresi) growth hormone. Salah satu growth hormone yang terstimulasi oleh aktivitas adalah brain derived neurotrophic factors (BDNF) yang berperan dalam kelangsungan hidup, pertumbuhan, diferensiasi dan plastisitas sel saraf (Reichardt, 2006). Sebagaimana diketahui bahwa pembelajaran motorik berhubungan dengan plastisitas sel saraf di otak dan sirkuitnya dalam sistem motorik (Emerick et al., 2003). Hasil penelitian menunjukkan adanya perbedaan yang signifikan antara perubahan kemampuan motor control antara kelompok yang diintervensi dengan aquatic aerobic activity dibandingkan yang diintervensi dengan land based activity. Aquatic aerobic activity mampu meningkatkan kemampuan motor control dan perkembangan gross motor yang lebih banyak dibandingkan land based activity. Hasil penelitian ini mengindikasikan adanya pengaruh kapasitas cardiovascular terhadap perkembangan motorik

Aquatic aerobic activity adalah suatu bentuk latihan yang memberikan tekanan yang minimal di persendiaan dibandingkan land based activity (Kelly \& Darrah, 2005). Gerakan yang dapat dilakukan di dalam aquatic aerobic activity dapat menyediakan stimulasi gerak pada semua plane of movement (sagital, frontal, tranversal) baik dalam aksis vertikal maupun horizontal. Buoyancy membantu menurunkan massa tubuh dan dapat digunakan untuk menyokong atau menyediakan tahanan, yang memungkinkan klien bergerak lebih leluasa di dalam air dibandingkan di darat. Land based activity tidak mampu menyediakan semua gerakan dengan bebas, karena gaya gravitasi dan keterbatasan ruang.
Perubahan kemampuan motor control dan perkembangan gross motor yang lebih banyak pada kelompok pasien $\mathrm{CP}$ yang diintervensi aquatic aerobic activity dibandingkan yang diintervensi land based activity, selaras dengan penilaian orang tua pasien. Hasil pemeriksaan dengan COPM menunjukkan adanya perubahan nilai rata-rata yang lebih tinggi pada komponen performance dan satisfaction dari kelompok pasien yang diintervensi aquatic aerobic activity.

\section{KESIMPULAN DAN SARAN}

Proporsi sampel penelitian, berdasarkan jenis kelamin diketahui didominasi oleh sampel berjenis kelamin laki-laki $(56,67 \%)$ dan tipe $\mathrm{CP}$ yang terbanyak adalah spastik diplegia $(50 \%)$.

Perkembangan kemampuan basic motor control (skor Bobath Chart) pasien $\mathrm{CP}$ lebih tinggi setelah menjalani intervensi (rata-rata $=73,80$ ) dibandingkan sebelum menjalani intervensi (rata-rata $=69,73)$.

Perkembangan kemampuan gross motor (skor GMFM) pasien CP lebih tinggi setelah menjalani intervensi (ratarata $=162,13$ ) dibandingkan sebelum menjalani intervensi (rata-rata $=154,80$ ).

Perkembangan kemampuan basic motor control pada pasien $\mathrm{CP}$ sebelum intervensi berbeda secara signifikan dengan setelah intervensi, baik yang diintervensi aquatic aerobic activity ( $\mathrm{p}$ value $=0,000)$ maupun land based activity (p-value $=0,005)$.

Perkembangan kemampuan gross motor pada pasien $\mathrm{CP}$ sebelum intervensi berbeda secara signifikan dengan setelah intervensi, baik yang diintervensi aquatic aerobic activity ( $\mathrm{p}$-value $=0,000$ ) maupun land based activity ( $\mathrm{p}$-value $=0,005$ ). 
Perubahan

perkembangan kemampuan basic motor control pada pasien $\mathrm{CP}$ yang memperoleh intervensi aquatic aerobic activity berbeda secara signifikan dengan yang diintervensi land based activity ( $\mathrm{p}$-value $=0,002)$. Perubahan kemampuan basic motor control lebih signifikan pada kelompok sampel yang memperoleh intervensi aquatic aerobic activity.

Perubahan

perkembangan

kemampuan gross motor pada pasien $\mathrm{CP}$ yang memperoleh intervensi aquatic aerobic activity berbeda secara signifikan dengan yang diintervensi land based activity $(\mathrm{p}$-value $=0,001)$. Perubahan kemampuan gross motor lebih signifikan pada kelompok sampel yang memperoleh intervensi aquatic aerobic activity.

Penilaian orang tua terhadap performance dan satisfaction kemampuan fungsional pasien $\mathrm{CP}$ lebih banyak mengalami peningkatan pasca memperoleh intervensi aquatic aerobic activity (rata-rata perubahan 0,13 dan $0,47)$ dibandingkan land based activity (rata-rata perubahan 0,07 dan 0,27).

Hasil penelitian ini telah menunjukkan bahwa aquatik aerobic activity telah memberikan pengaruh yang signifikan terhadap peningkatan kemampuan basic motor control, gross motor dan occupational performance skills pada pasien cerebral palsy. Berdasarkan hasil tersebut, diharapkan aquatik aerobic activity dapat digunakan atau ditambahkan ke dalam program atau kurikulum terapi bagi anak cerebral palsy di YPAC Cabang Surakarta.

Terapi lain dan medika mentosa berpengaruh terhadap mekanisme fisiologis perbaikan jaringan. Oleh karena itu penelitian dengan topik serupa disarankan turut memonitor jenis, intensitas/dosis dan frekuensi dari terapi lain yang dijalani dan obat yang dikonsumsi.

\section{DAFTAR RUJUKAN}

Emerick, A.J., Neafsey, E.J., Schwab, M.E., \& Kartje, G.L. (2003). Functional reorganisastion of motor cortex in adult rats after cortical lesion and treatment with monoclonal antibody IN-1. J.Neurosci. 23(12):4826-4830.

Fowler, E., Kolobe, T.H., \& Damiano, D. (2007). Promotion of physical fitness and prevention of secondary condition for children with cerebral palsy: section on pediatrics research summit proceedings. Phys Ther. 87:14951510.

Kelly, M. \& Darrah, J. (2005). Aquatic exercise for children with cerebral palsy. Dev Med Child Neurol. 47:838-842.

Reichardt, L.F. (2006). Neurotrophinregulated signaling pathways. Philos.Trans.R.Soc.Lond.B.Biol.S ci. 361:1545-1564.

Retarekar, R., Fragala-Pinkham, M.A., \& Townsend, E.L. (2009). Effects of aquatic aerobic exercise for a child with cerebral palsy: single-subject design. Pediatrics of the American Physical Therapy Association.

Saharso, D. (2006). Cerebral palsy : diagnosis dan tatalaksana. Surabaya : FK. Unair RSU. Dr. Soetomo Surabaya.

Thorpe, D., Reilly, M., \& Case, L. (2005). The effects of an aquatic resistive exercise program on ambulatory children with cerebral palsy. J. Aquat Psys Ther. 13:21-34. 